\title{
分子格的直积分解与广义序同态的构造
}

\author{
樊 嘉宏斌 郑崇友 \\ (北京师范学院数学系)
}

文献 [1,2] 建立了完全分配格上的点式拓扑理论, 即拓扑分子格理论, 本文将利用分子 概念 ${ }^{[13}$ 建立分子格的直积分解, 而后在此基础上给出分子格之间的广义序同态的构造.

\section{一、预 备}

本文沿用文献 $[1,3]$ 中的概念和记号, 用 $L(M)$ (简记 $L$ ) 表示分子格, 即完全分配格, 其中 $M$ 为 $L$ 中分子之集. 格中最大元与最小元分别用 1 与 0 表示. 设 $\left\{L_{i}\left(M_{i}\right) \mid i \in I\right\}$ 是分子 格之族, 用 $\prod_{i \in 1} L_{i}$ 表示其直积 ${ }^{[4]}$, 可以证明 $\prod_{i \in 1} L_{i}$ 是分子格, 其分子之集为

$$
\left\{p_{i}(a) \mid a \in M_{i}, i \in I\right\}^{[3]},
$$

其中对于 $i_{0} \in I$, 映射 $y_{i_{0}}: L_{i_{0}} \rightarrow \prod_{i \in I} L_{i}$ 定义为 $p_{i_{0}}(x)-\left\{x_{i}\right\}_{i \in l,}$, 此处 $x \in L_{i_{0}}$, 且

$$
x_{i}= \begin{cases}x, & i=i_{0} \\ 0, & i \neq i_{0}\end{cases}
$$

设 $L$ 是分子格, $\left\{L_{i} \mid i \in I\right\}$ 与 $\left\{L_{j}^{\prime} \mid j \in J\right\}$ 都是分子格之族. (1) 若

$$
L \cong \prod_{i \in I} L_{i}
$$

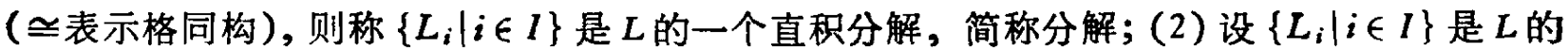
一个分解. 若存在 $i_{0} \in I$ 使得 $L \cong L_{i_{0}}$, 且 $\forall i \in I$, 当 $i \neq i_{0}$ 时,有 $L_{i}=\{0\}$, 则称 $\left.\left\{L_{i}\right\} i \in I\right\}$ 是 $L$ 的一个平凡分解； (3) 若 $L$ 只有平凡分解, 则称 $L$ 是既约的; (4) 对于 $L$ 的两个分解

$$
\left\{L_{i} \mid i \in I\right\} \text { 与 }\left\{L_{i}^{\prime} \mid j \in J\right\},
$$

若存在双射 $\sigma: l \rightarrow J$ 使得 $\forall i \in I$, 有 $L_{i} \cong L_{o(i)}^{\prime}$, 则称 $\left\{L_{i} \mid i \in I\right\}$ 与 $\left\{L_{i}^{\prime} \mid j \in J\right\}$ 是 $L$ 的等价 分解; (5) 设 $\left\{L_{i} \mid i \in I\right\}$ 是 $L$ 的一个分解, 若 $\forall i \in I$, 有 $L_{i} \neq\{0\}$, 且 $L_{i}$ 是既约的, 则称 $\left\{L_{i} \mid i \in I\right\}$ 是 $L$ 的既约分解. 以上诸定义本质上来自文献 [6].

对于广义序同态,本文采用文献 [7]或 [3] 中给出的定义.

\section{二、分子格的直积分解}

定理 1 设 $L(M)$ 是分子格, $a \in M$. 记 $[a]=\left\{m \in M \mid \exists m_{1}, m_{2}, \cdots, m_{k} \in M\right.$ 使得 $\left.a \wedge m_{1} \neq 0, m_{1} \wedge m_{2} \neq 0, \cdots, m_{k} \wedge m \neq 0\right\}$, 则 $L[a]-\{A \in L \mid A$ 可表为 [a] 中元素之并 $\}$ $\cup\{0\}$ 是 $L$ 的完备子格（因而是分子格），其分子之集为 $[a], L[a]$ 称作 $L$ 的由 $a$ 决定的主子 格.

本文 1986 年 5 月 19 日收到. 
证 只需证 $L[a]$ 对任意交封闭. 先考虑特殊情形. 设 $\forall a \in O, a_{\alpha} \in[a]$. 若

$$
\bigwedge_{a \in D} a_{\alpha}=0,
$$

则 $\bigwedge_{a \in D} a_{a} \in L[a]$. 故不妨设 $\bigwedge_{a \in Q} a_{a} \neq 0 . \forall b \in M$, 若 $b \leqslant \bigwedge_{\in \in Q} a_{e}$, 则 $\forall \beta \in \Omega$, 恒有 $a_{\beta} \geqslant b$. 于是 $b \in\left[a_{B}\right]-[a]$, 所以 $\bigwedge_{a \in Q} a_{\alpha} \in L[a]$.

再设 $\forall_{a} \in \Omega . A_{a} \in L[a]$, 且 $A_{\alpha} \neq 0$. 记 $A_{\alpha}-\bigvee_{i \in I_{\alpha}} a_{i}^{(a)}$, 其中 $\forall i \in I_{\alpha}, a_{i}^{(a)} \in[a]$. 从

$$
\bigwedge_{a \in D} A_{a}=\bigwedge_{\in \in D}\left(\bigvee_{i \in I_{\alpha}} a_{i}^{(a)}\right)-\bigvee_{q \in u_{\alpha}}\left(\bigwedge_{a \in D} a_{(\alpha)}^{(a)}\right)
$$

与上述已证的结论可得 $\bigwedge_{a \in Q} A_{a} \in L[a]$. 当某个 $A_{a}-0$ 时, 结论显然.

$L[a]$ 作为分子格,其分子之集显然是 $[a]$.

定坬 2 设 $L(M)$ 是分子格. (1) 设 $a, b \in M$. 若 $L[a] \neq L[b]$, 则 $\forall A \in L[a]$, 与 $\forall B \in L[b]$, 有 $A \wedge B-0$; (2) 设 $a \in M, A \in L$. 若 $A \leqslant \vee L[a]$, 则 $A \in L[a]$.

证 (1) 是显然的. (2) 设 $A \leqslant \vee L[a]-\vee[a]$. 若 $A=0$, 则 $A \in L[a]$. 所以设 $A \neq 0$. 任取 $b \in M$, 且 $b \leqslant A$, 则

$$
0<b-b \wedge A \leqslant b \wedge(\bigvee[a])-b \wedge\left(\bigvee_{\in[a]} c\right)-\bigvee_{c \in[a]}(b \wedge c)
$$

于是存在 $c \in[a]$ 使得 $b \wedge c \neq 0$, 即 $b \in[c]-[a]$, 故 $A \in L[a]$.

定理 3 设 $L$ 是分子格. 则 $L$ 的主子格全体作成的族 $\left\{L_{i} \mid i \in I\right\}$ 是 $L$ 的一个分解.

证 对 $\forall i \in L$, 命 $f(A)-\left\{A \wedge e_{i}\right\}_{i \in l}$, 其中 $\forall i \in I, e_{i}-\vee L_{i}$. 因为

$$
\forall i \in I, A \wedge e_{i} \leqslant e_{i} \text {, }
$$

故由定理 2(2) 知 $f(A) \in \prod_{i \in t} L_{i}$. 所以 $f: L \rightarrow \prod_{i \in t} L_{i}$ 是一个映射. 易证 $t$ 是单满广义序同 态, 从而是同构 (文献 [1] 中命题 3.6). 所以 $\left\{L_{i} \mid i \in I\right\}$ 是 $L$ 的一个分解.

定理 4 设 $L(M)$ 是分子格, 则下列三条件等价:

(1) $L(M)$ 是既约的;

(2) 对 $L$ 的任意分子 $a, b \in M$, 存在 $m_{1}, m_{2}, \cdots, m_{k} \in M$ 使得

$$
a \wedge m_{1} \neq 0, m_{1} \wedge m_{2} \neq 0, \cdots, m_{k} \wedge b \neq 0 ;
$$

(3) $\forall a \in M$, 有 $L-L[a]$.

证 $(1) \Rightarrow(2)$ 和 $(2) \Leftrightarrow(3)$ 是显然的. 故只需证明 (2) $\Rightarrow(1)$. 设 $L(M)$ 满足条件 (2). 设 $\left\{L_{i}\left(M_{i}\right) \mid i \in I\right\}$ 是 $L(M)$ 的任意分解. 则有同构 $g: \prod_{i \in I} L_{i} \rightarrow L$, 且

$$
M=\left\{g \circ p_{i}(a) \mid a \in M_{i}, i \in I\right\} \text {. }
$$

任取 $\prod_{i \in I} L_{i}$ 中的分子 $p_{i_{0}}(x), p_{i_{0}}(y)$, 其中 $i_{0}, j_{0} \in I, x \in M_{i_{0}}$ 与 $y \in M_{i_{0}}$, 则

$$
g \circ p_{i_{0}}(x), g \circ p_{i_{0}}(y) \in M \text {. }
$$

由条件 (2), 存在 $\prod_{i \in I} L_{i}$ 中分子 $p_{i_{1}}\left(z_{1}\right), p_{i_{2}}\left(z_{2}\right), \cdots, p_{i_{k}}\left(z_{k}\right)$, 其中 $i_{1}, i_{2}, \cdots, i_{k} \in I, z_{i} \in M_{i_{i}}$, 
$1=1,2, \cdots, k$, 使得

$$
g \circ p_{i_{0}}(x) \wedge g \circ p_{i_{1}}\left(z_{1}\right) \neq 0, \cdots, g \circ p_{i_{k}}\left(z_{k}\right) \wedge g \circ p_{i_{0}}(y) \neq 0 .
$$

但 $g$ 是同构,从而

$$
p_{i_{0}}(x) \wedge p_{i_{1}}\left(z_{1}\right) \neq 0, \cdots, p_{i_{k}}\left(z_{k}\right) \wedge p_{i_{0}}(y) \neq 0 .
$$

于是 $i_{0}=i_{1}=\cdots=i_{k}=j_{0}, L \cong L_{i_{0}}$, 且 $\forall i \in I$, 当 $i \neq i_{0}$ 时有 $L_{i}=\{0\}$. 所以 $\left\{L_{i} \mid i \in I\right\}$ 是 $L$ 的平凡分解, 即 $L$ 是既约的.

定理 5 任何分子格必有既约分解,并且它的任意两个既约分解都是等价的.

证第一部分由定理 3 和 4 得到,第二部分由下面的定理 7(3) 即证.

定理 6 设 $L$ 是分子格, 则 $L$ 同构于某个 $L_{1}^{x}$ (其中 $L_{1}$ 是既约分子格, $X$ 是通常集) 当且 仅当 $L$ 的所有主子格都同构.

\section{三、广义序同态的构造}

定理 7 设 $L(M), L^{\prime}\left(M^{\prime}\right)$ 都是分子格, $\left\{L_{i}\left(M_{i}\right) \mid i \in I\right\}$ 和 $\left\{L_{i}^{\prime}\left(M_{i}^{\prime}\right) \mid i \in J\right\}$ 分别是 $L$ 和 $L^{\prime}$ 的主子格之族. $f: L \rightarrow L^{\prime}$ 是广义序同态. 则 (1) $\forall i \in I$, 存在 $j \in J$ 使得 $f\left(L_{i}\right) \subset L_{i}^{\prime} ;$ (2) $f$ 诱出一个相关的分明映射 $f: l \rightarrow J$, 且 $\forall i \in I$, 给出广义序同态 $f_{i}: L_{i} \rightarrow L_{z(i)}^{\prime}$ 使得 $f_{i}-f \mid L_{i}$; (3) $f$ 是同构当且仅当与 $f$ 相关的分明映射 $f$ 是双射,且 $\forall i \in I, f \mid L_{i}$ 是同构.

证 为方便起见, 不妨约定 $L=\prod_{i \in I} L_{i}$ 与 $L^{\prime}=\prod_{i \in J} L_{i}^{\prime}$.

(1) 任取 $a, b \in M_{i}(i \in I)$, 则存在 $m_{1}, m_{2}, \cdots, m_{k} \in M_{i}$ 使得

$$
a \wedge m_{1} \neq 0, m_{1} \wedge m_{2} \neq 0, \cdots, m_{k} \wedge b \neq 0 \text {. }
$$

因为 $f$ 是广义序同态, $f^{-1} \circ f \geqslant i$ ( $i$ 为恒同映射), 且 $f^{-1}$ 保交 ${ }^{[3]}$, 于是得

$$
\begin{gathered}
0<a \wedge m_{1} \leqslant f^{-1} f(a) \wedge f^{-1} f\left(m_{1}\right)=f^{-1}\left(f(a) \wedge f\left(m_{1}\right)\right) ; \\
0<m_{1} \wedge m_{2} \leqslant f^{-1} f\left(m_{1}\right) \wedge f^{-1} f\left(m_{2}\right)=f^{-1}\left(f\left(m_{1}\right) \wedge f\left(m_{2}\right)\right) ; \\
\cdots \cdots \\
0<m_{k} \wedge b \leqslant f^{-1} f\left(m_{k}\right) \wedge f^{-1} f(b)=f^{-1}\left(f\left(m_{k}\right) \wedge f(b)\right) .
\end{gathered}
$$

但是 $f^{-1}(0)=0$, 从而

$$
f(a) \wedge f\left(m_{1}\right) \neq 0, f\left(m_{1}\right) \wedge f\left(m_{2}\right) \neq 0, \cdots, f\left(m_{k}\right) \wedge f(b) \neq 0 .
$$

所以 $f(a), f(b)$ 在 $L^{\prime}$ 的同一个主子格 $L_{i}^{\prime}$ ， 从 $f$ 的保并性即知 $f\left(L_{i}\right) \subset L_{i}^{\prime}$. 显然这样的 $i \in J$ 唯一.

(2) 对于 $i \in I$, 若 $f\left(L_{i}\right) \subset L_{i}^{\prime}$, 命 $f(i)=j$, 则 $f: I \rightarrow J$ 是分明映射. $\forall i \in I$, 命 $f_{i}=f \mid L_{i}$, 则有 $f_{i}=f \mid L_{i}=f \circ p_{i}$ 。 这是广义序同态的复合, 从而 $\forall i \in I, f_{i}$ 是广义序同态.

（3）若 $f$ 是同构, 则 $\forall i \in I, f_{i} \Rightarrow f \circ p_{i}$ 是 $L_{i}$ 到 $L^{\prime}$ 的一个主子格上的同构, 易见这个主子 格就是 $L_{i(i)}^{\prime}$ 。

现在设 $f$ 是双射, 且 $\forall i \in I, f_{i}$ 是同构,则有同构 $h: \prod_{i \in l} L_{i} \rightarrow \prod_{i \in j} L_{i}^{\prime}$, 这里

$$
h\left(\left\{x_{i}\right\}_{i \in I}\right)=\left\{f_{i}\left(x_{i}\right)\right\}_{i \in I} \text {. }
$$

由上述约定, 则 $f=h$ 是同构.

定理 8 设 $L, L^{\prime}$ 都是分子格， $\left\{L_{i} \mid i \in I\right\}$ 是 $L$ 的主子格族. 若 $\forall i \in I$ 有广义序同态 $f_{i}: L_{i} \rightarrow L^{\prime}$, 则存在唯一广义序同态 $f: L \rightarrow L^{\prime}$ 使得 $\forall i \in l, f_{i}=f \mid L_{i}$. 
证将 $L$ 与 $\prod_{i \in t} L_{i}$ 等同, 则由直积的性质 ${ }^{[3]}$ 即证.

定理 9 设 $L, L^{\prime}$ 都是分子格, $f: L \rightarrow L^{\prime}$ 是广义序同态. 则 $f-\left(f^{-1}\right)^{-1}$ 当且仅当 $f$ 诱 出的分明映射 7 是双射, 且 $\forall i \in I$, 有 $\left(f_{i}^{-1}\right)^{-1}=f_{i}$ 。

证 $\left(f^{-1}\right)^{-1}-f$ 当且仅当 $f$ 是双射 ${ }^{[33}$, 再由定理 $7(3)$ 即证.

致谢：审稿人对本文提出了有益的意见，作者深表谢意.

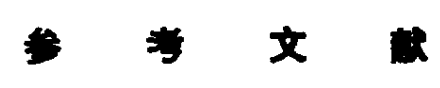

[1]王国㑈,陕西师范大学学报，1985，1:1-17.

[2]王国俊,陕西师范大学学报, 1985, 2:1-15.

[3] 刘应明,四川大学学报, 1985, 4:25-32.

[4] Grătzer, G., General Lattice Thcory, Berlin, 1978.

[5] 类太和,科学通很, 31(1986)，4:244-247。

[6]中山正,格论(茥克诚译)，上海科学技术出版社，1964.

[7]王国化,东北数学, 1985, 2:141-152. 